\title{
Posttraumatic intraocular pressure elevation and associated factors in patients with zone I open globe injuries
}

\author{
Zon I açık göz yaralanması olan hastalarda \\ posttravmatik göz içi basıncı yükselmesi ve ilişkili faktörler
}

\author{
Uğur ACAR, ${ }^{1 *}$ Elvin H. YILDIZ, ${ }^{2}$ Damla ERGINTÜRK ACAR, ${ }^{1}$ Uğur Emrah ALTIPARMAK, ${ }^{2}$ \\ Züleyha YALNIZ AKKAYA, ${ }^{2}$ Ayşe BURCU, ${ }^{2}$ Nurten ÜNL ${ }^{2}$
}

\section{BACKGROUND}

The object of this study was to determine factors that might be associated with intraocular pressure (IOP) elevation after anterior segment open globe injuries (zone I).

\section{METHODS}

Data were obtained from the records of 68 patients who experienced zone I open globe injury between January 2008 and October 2010. Group I was composed of patients with chronically elevated IOP of at least $21 \mathrm{mmHg}$ within a 1-year follow-up period. The rate of posttraumatic IOP elevation and associated structural and functional risk factors were evaluated.

\section{RESULTS}

Of the 68 patients, 17 (25\%) developed posttraumatic IOP elevation (Group 1). The mean age in group I was significantly older compared to group II ( $36.8 \pm 24.4$ and $15.7 \pm 15.3$ years, respectively $[p=0.003])$. Iris damage, postoperative inflammation, and use of long-term corticosteroids were significantly greater in group I $(\mathrm{p}<0.001, \mathrm{p}<0.001, \mathrm{p}=0.005$ respectively). In group I, 13 of 17 patients $(76.5 \%)$ had a wound size larger than $6 \mathrm{~mm}$ compared to only one patient $(1 / 51,2 \%)$ in group II, and the result was statistically significant $(p<0.001)$. The size of wound larger than $6 \mathrm{~mm}$ also retained its statistical significance in multivariate analysis ( $\mathrm{p}<0.001$, odds ratio: 162.5 ).

\section{CONCLUSION}

This study shows a significant relationship between larger wound size $(>6 \mathrm{~mm})$ and elevation of IOP after trauma in zone I open globe injuries.

Key Words: Intraocular pressure elevation; ocular trauma; penetrating ocular injury; traumatic glaucoma.

\section{AMAÇ}

Ön segment (zon I) açık göz yaralanmalarında göz içi basıncı (GİB) yükselmesi ile ilişkili risk faktörlerini belirlemektir.

\section{GEREÇ VE YÖNTEM}

Ocak 2008-Ekim 2010 tarihleri arasında zon I açık göz yaralanması geçirmiş 68 hastanın kayıtları incelendi. İlk bir y1llık takiplerde GïB kronik olarak $21 \mathrm{mmHg}$ ve üzerinde seyreden olgular grup I, $21 \mathrm{mmHg}$ 'nin altında seyreden olgular grup II olarak belirlendi. Postravmatik GİB yükselme oranı ve ilişkili yapısal ve fonksiyonel risk faktörleri değerlendirildi.

\section{BULGULAR}

Altmışsekiz hastanın 17'sinde (\%25) postravmatik GIB yüksekliği saptandı (Grup I). Ortalama yaş grup I'de grup II'ye kıyasla anlamlı oranda yüksek idi (sırasıly $36,8 \pm 24,4$ ve $15,7 \pm 15,3$ y1l $[p=0,003])$. Grup I'de iris hasar, ameliyat sonras1 enflamasyon ve uzun dönem kortikosteroid kullan1$\mathrm{m} 1$ anlamlı oranda daha sik idi. (sirasiyla $\mathrm{p}<0,001, \mathrm{p}<0,001$, $\mathrm{p}=0,005)$. Grup I'deki 17 hastanın 13 'ünde $(\% 76,5)$, grup II'de sadece 1 hastada $(1 / 51, \% 2)$ yara boyutu $6 \mathrm{~mm}$ 'den uzun idi ve bu sonuç istatistiksel olarak anlamlı idi $(\mathrm{p}<0,001)$. Ayrıca çok değişkenli analizde, yara boyutunun $6 \mathrm{~mm}$ 'den fazla olmasının istatistiki anlamlılığı korundu ( $<<0,001$, odd oran1: 162,5).

\section{SONUÇ}

Bu çalışma, zon I açık göz yaralanmalarında yara boyutunun $6 \mathrm{~mm}$ ve üzeri olması ile posttravmatik GİB yükselme arasında çok yakın ilişki olduğunu göstermektedir.

Anahtar Sözcükler: Göz içi basıncı yükselmesi; oküler travma; penetran oküler yaralanma; travmatik glokom.

\footnotetext{
${ }^{1}$ Department of Ophthalmology, Kastamonu State Hospital, Kastamonu;

${ }^{2}$ Department of Ophthalmology, Ankara Training and Research Hospital, Ankara, Turkey.

\#Current affiliation: Department of Ophthalmology, Hacettepe University, Kastamonu Faculty of Medicine, Ankara, Turkey.
}

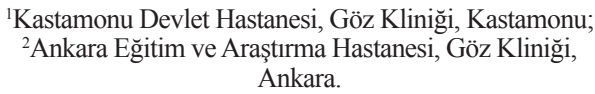

${ }^{1}$ Kastamonu Devlet Hastanesi, Göz Kliniği, Kastamonu;

${ }^{2}$ Ankara Eğitim ve Araştırma Hastanesi, Göz Kliniği, Ankara.

"Şimdiki kurumu: Hacettepe Üniversitesi Kastamonu Tıp Fakültesi Göz Hastalıkları Anabilim Dalı, Ankara. 
Open globe injury, defined as a full-thickness laceration of the eye wall, ${ }^{[1]}$ is one of the major causes of monocular blindness. ${ }^{[2]}$ In cases with open globe injuries, damage to the trabecular meshwork, intraocular hemorrhage, and inflammation predisposes traumatized eyes to the prolonged elevations in intraocular pressure (IOP), which can lead to glaucomatous changes in the optic nerve.

Several studies have focused on the development of IOP elevation after blunt ocular injuries and specific traumatic sequelae such as traumatic hyphema and angle recession. ${ }^{[3-6]}$ However, there are only a few articles examining the overall risk of developing IOP elevation and its risk factors after penetrating ocular injury. ${ }^{[7,8]}$ A 3.4\% incidence of IOP elevation and secondary glaucoma after ocular contusion has been reported during six-month follow-up. ${ }^{[3]}$ During the 10 years after trauma, the percent of incidence could rise up to $10 \%$. $^{[9]}$

The injury zone is defined by the location of the most posterior, full-thickness aspect of the globe opening. ${ }^{[10]}$ Zone I injuries are limited to cornea and limbus. Zone II injuries involve the anterior $5 \mathrm{~mm}$ of the sclera. Zone III injuries extend more than $5 \mathrm{~mm}$ posterior to the corneoscleral limbus.

The aim of our study is to analyze a group of patients with zone I open globe injuries who developed posttraumatic IOP elevation to determine whether any risk factors could be identified that might relate to IOP elevation.

\section{MATERIALS AND METHODS}

The investigations were performed according to the guidelines of the Declaration of Helsinki and the Institutional Ethic Committee approval was obtained. Operating department records were reviewed to identify all patients who had undergone repair of an open globe injury from 1 January 2008 to 1 October 2010. Case records were examined to determine the zone of injury. The subjects of the study were patients who experienced zone I injuries. The cases with sclera and posterior segment involvement (vitreous, choroid, retina) and the cases with intraocular foreign bodies were excluded. Posttraumatic IOP elevation was defined based on the presence of a chronically elevated IOP of al least $21 \mathrm{mmHg}$ within one-year follow-up.

The variables studied included age at the time of injury, baseline visual acuity, the presence of lens damage, iris damage, inflammation, and need for anterior segment reformation surgery. Stratification variables included sex (female, male), size of the repaired wound (0-3 mm, 3-6 mm, and $>6 \mathrm{~mm})$, and the length of time the patient remains on corticosteroids $(<2$ months, 2-6 months, $>6$ months).

\section{Statistical analysis}

Results are expressed as mean \pm standard deviation (SD). Statistical analysis was performed with SPSS software (SPSS for Windows, version 15.0, Chicago, Illinois). Conditional logistic regression analysis was used to model the relationship and account for any correlation between posttraumatic secondary glaucoma and baseline demographic characteristics, size of the wound repaired, other anterior segment structures involved in the initial injury, additional surgeries performed, and length of time on the current steroid regimen. The data were analyzed using univariate and multivariate models. A $\mathrm{p}<0.05$ was considered statistically significant.

\section{RESULTS}

Between January 2008 and October 2010, a total of 132 patients with open globe injuries were identified. Of these, $64(48.5 \%)$ had a posterior segment involvement and thus were excluded. Of the remaining 68 patients with isolated anterior segment open globe injury (zone I), 17 (25\%) developed IOP elevation. Demographics and other characteristics of patients with (Group I) and without (Group II) posttraumatic IOP elevation are shown in Table 1. The groups were comparable with respect to gender and baseline visual acuity, but Group I patients were significantly older compared to the Group II patients, with a mean age of $36.8 \pm 24.4$ years in Group I and $15.7 \pm 15.3$ years in Group II ( $\mathrm{p}=0.003)$.

The number of patients with concurrent lens damage was not significantly different between the groups. However, instances of simultaneous iris damage and postoperative inflammation were significantly greater in Group I $(\mathrm{p}<0.001$ and $\mathrm{p}<0.001$, respectively). In Group I, 13 of 17 patients $(76.5 \%)$ had a wound size bigger than $6 \mathrm{~mm}$ compared to only one patient $(1 / 51,2 \%)$ in Group II, and the result was statistically significant $(\mathrm{p}<0.001)$. There was a statistically significant difference in risk of development of IOP elevation when comparing patients who had been on corticosteroids for greater than or equal to two months compared with those who had been using corticosteroids for less than two months ( $p=0.005)$. In terms of other variables studied, including the need for anterior segment reformation surgery, groups did not show significant differences $(\mathrm{p}>0.05)$.

In the multivariate analysis incorporating all of the variables including age at the time of injury, concurrent lens damage, and inflammation, prolonged use of corticosteroids lost its statistical significance, whereas the size of wound $(>6 \mathrm{~mm})$ retained its statistical significance $(\mathrm{p}<0.001$, odds ratio: 162.5) (Table 1$)$. 
Table 1. Demographics and other characteristics of the patients in the groups

\begin{tabular}{lccccc}
\hline Variables & $\begin{array}{c}\text { Group I } \\
(\mathrm{n}=17)\end{array}$ & $\begin{array}{c}\text { Group II } \\
(\mathrm{n}=51)\end{array}$ & $p$ & OR & $95 \%$ CI \\
\hline Mean age (year) & $36.8 \pm 24.4$ & $15.7 \pm 15.3$ & 0.003 & 1.053 & $1.021-1.086$ \\
Gender (female / male) & $4 / 13$ & $9 / 42$ & $>0.05$ & 1.436 & $0.379-5.440$ \\
Baseline distance visual acuity (LogMAR) & $1.97 \pm 0.96$ & $1.40 \pm 0.91$ & $>0.05$ & 1.988 & $1.087-3.638$ \\
Final corrected distance visual acuity (LogMAR) & $1.26 \pm 0.99$ & $0.58 \pm 0.49$ & $>0.05$ & 4.215 & $1.471-12.080$ \\
Size of the wound $>6$ mm & $13(76.47 \%)$ & $1(1.96 \%)$ & $<0.001$ & 162.500 & $16.710-1580.274$ \\
Presence of lens damage & $12(70.59 \%)$ & $23(45.10 \%)$ & $>0.05$ & 2.922 & $0.898-9.509$ \\
Presence of iris damage & $15(88.23 \%)$ & $6(11.77 \%)$ & $<0.001$ & 56.250 & $10.238-309.037$ \\
Presence of inflammation & $15(88.23 \%)$ & $13(25.50 \%)$ & $<0.001$ & 21.923 & $4.408-109.041$ \\
Corticosteroids treatment $>2$ months & $7(41.18 \%)$ & $41(80.39 \%)$ & 0.005 & 5.857 & $1.786-19.210$ \\
\hline
\end{tabular}

OR: Odds ratio; CI: Confidence interval; a: LogMAR: Logarithm of the minimum angle of resolution.

\section{DISCUSSION}

The lifetime prevalence of ocular trauma is estimated to be $19.8 \%$ with a five-year incidence of $1.6 \%$. ${ }^{[11]}$ One of the most common causes of vision loss after trauma is a secondary glaucoma, which may occur late after the initial treatment and stabilization of other problems, but can also be present immediately after the injury. ${ }^{[12]}$ Many studies report that the most frequently involved age group is under 30 (the mean age is 20.9 years in our study). The most common cause of ocular trauma in children is playground accidents, whereas sport accidents and attacks are the leading causes in adults, and home and work accidents are the most frequent cause in the elderly. ${ }^{[12,13]}$ Girkin et al. ${ }^{[7]}$ reported that an overall incidence of posttraumatic IOP elevation after penetrating ocular trauma was $2.67 \%$, which is lower than the incidence found in our study $(17 / 68,25 \%)$. The difference between the studies may be because the current study was composed of patients with only zone I injuries, whereas in Girkin's study, patients with zone I, II, and III injuries were included. Based on these findings, it may be postulated that after zone I injuries, more severe damage occurs in the trabecular meshwork/Schlemm's canal (aqueous drainage system), compared to that in the ciliary body (aqueous production system); this may be the explanation for higher incidence of IOP elevation, as found in the current study. Although zone II and zone III injuries have worse prognosis than zone I injuries, it seems that zone I injuries are associated with higher risk of secondary IOP elevation.

One study reported that the factors leading to better prognosis in penetrating ocular traumas are the sharp nature of the damaging object, a visual acuity better than 20/200, injuries less than $10 \mathrm{~mm}$, and injuries localized to the anterior segment. ${ }^{[13]}$ Any penetrating injury can initiate inflammation that eventually leads to uveitic glaucoma. ${ }^{[8]}$ Inflammation must be carefully controlled and cycloplegia is usually recommended during the acute post-injury phase. Long-term use of corticosteroids is common in cases of penetrating trauma which can lead to elevated IOP. The rise in IOP tends to occur two to three weeks after initiation of therapy and is dose-dependent. ${ }^{[14]}$ Even after cessation of corticosteroid treatment, sometimes patients require lifelong IOP control, perhaps owing to irreversible changes in the trabecular meshwork. ${ }^{[15]}$

Initial IOP is usually low after open globe injury, but after wound closure, IOP elevation and subsequent glaucoma may develop. Unlike blunt trauma, the open globe injuries tend not to follow any predictable pattern, and posttraumatic IOP elevation-secondary glaucoma is often associated with multiple factors including structural alteration from injury and blockage of trabecular meshwork or secondary responses such as inflammation. ${ }^{[8]}$ At least five different mechanisms of glaucoma formation are described after penetrating ocular traumas: shallow anterior chamber, inflammation, intraocular hemorrhage, lens-induced glaucoma, and epithelial or fibrous ingrowth. ${ }^{[13]}$

A review of data from US Eye Injury Register found increasing age, poor baseline visual acuity, angle recession, hyphema, and lens injury to be independent risk factors for developing posttraumatic IOP elevation-glaucoma after ocular contusion. Advancing age, lens injury, baseline visual acuity below $20 / 200$, and anterior chamber inflammation were associated with the development of post-traumatic secondary glaucoma following penetrating ocular trauma. ${ }^{[3,7]}$ In these last two studies, traumatic glaucoma was recorded at any time within six months of the injury, based on the physician's opinion alone. Despite its large numbers, traumatic glaucoma is limited by the absence of standardized criteria for diagnosis of posttraumatic secondary glaucoma.

Sihota et al. ${ }^{[4]}$ stated posttraumatic hyphema-secondary glaucoma were associated with ciliary body damage. These ciliary body injuries would lead to an 
inflammatory response not only at the site of injury, but also throughout the ciliary body and in the contiguous iris and trabecular meshwork. Uveal inflammation and injury is generally resolved using a fibroblastic response, as seen in the iris or the choroid. Such a reparative process in the ciliary body would necessarily involve the adjoining trabecular meshwork, decreasing aqueous outflow and raising IOP. In our study, we found a significant relationship between the size of wound and the development of posttraumatic IOP elevation after zone I open globe injuries. In the multivariate analysis incorporating all of the variables found significant in univariate analysis including age at the time of injury, concurrent lens damage, inflammation, and prolonged use of corticosteroids lost their statistical significance whereas the size of wound retained its significance.

By the time acute symptoms and signs of trauma have subsided, patients may be unaware of a chronically elevated IOP. It is important to be able to identify eyes that have a greater risk of postrraumatic IOP elevation-secondary glaucoma and to review them carefully, so that appropriate therapy may be initiated as early as possible. As found in our study, trabecular meshwork injury, impaired aqueous drainage, and secondary intraocular pressure elevation are more frequently associated with larger wounds (defined as the wounds larger than $6 \mathrm{~mm}$ in the current study) than with smaller size wounds. It might, at this point, be appropriate to state that clinicians should carefully follow up the patients with zone I open globe injuries, especially those with relatively larger wound sizes with regard to the development of chronic IOP elevation.

In conclusion, posttraumatic secondary glaucoma is a common and often devastating consequence of ocular injury. A thorough knowledge of the risk factors for posttraumatic IOP elevation and careful examination are required for rapid identification of affected patients, especially those who are predisposed to secondary glaucoma. Patient education, careful surveillance, and early intervention provide the posttraumatic patient with the best chance for long term vision preservation. Results of this current study may be useful in determining individuals who are most likely to develop posttraumatic IOP elevation after zone I open globe injuries. Although each case was able to match to three cases in control group, the limitation of the study was the retrospective nature and relatively small sample size. Further evaluation of patients with posttraumatic IOP elevation should be carried out on a larger population.

Conflict-of-interest issues regarding the authorship or article: None declared.

\section{REFERENCES}

1. Kuhn F, Morris R, Witherspoon CD, Heimann K, Jeffers JB, Treister G. A standardized classification of ocular trauma. Ophthalmology 1996;103:240-3.

2. Rahman I, Maino A, Devadason D, Leatherbarrow B. Open globe injuries: factors predictive of poor outcome. Eye (Lond) 2006;20:1336-41.

3. Girkin CA, McGwin G Jr, Long C, Morris R, Kuhn F. Glaucoma after ocular contusion: a cohort study of the United States Eye Injury Registry. J Glaucoma 2005;14:470-3.

4. Sihota R, Kumar S, Gupta V, Dada T, Kashyap S, Insan R, et al. Early predictors of traumatic glaucoma after closed globe injury: trabecular pigmentation, widened angle recess, and higher baseline intraocular pressure. Arch Ophthalmol 2008;126:921-6.

5. De Leon-Ortega JE, Girkin CA. Ocular trauma-related glaucoma. Ophthalmol Clin North Am 2002;15:215-23.

6. Shiuey Y, Lucarelli MJ. Traumatic hyphema: outcomes of outpatient management. Ophthalmology 1998;105:851-5.

7. Girkin CA, McGwin G Jr, Morris R, Kuhn F. Glaucoma following penetrating ocular trauma: a cohort study of the United States Eye Injury Registry. Am J Ophthalmol 2005;139:100-5.

8. Milder E, Davis K. Ocular trauma and glaucoma. Int Ophthalmol Clin 2008;48:47-64.

9. Kaufman JH, Tolpin DW. Glaucoma after traumatic angle recession. A ten-year prospective study. Am J Ophthalmol 1974;78:648-54.

10. Pieramici DJ, Sternberg P Jr, Aaberg TM Sr, Bridges WZ Jr, Capone A Jr, Cardillo JA, et al. A system for classifying mechanical injuries of the eye (globe). The Ocular Trauma Classification Group. Am J Ophthalmol 1997;123:820-31.

11. Wong TY, Klein BE, Klein R. The prevalence and 5-year incidence of ocular trauma. The Beaver Dam Eye Study. Ophthalmology 2000;107:2196-202.

12. Ozer PA, Yalvac IS, Satana B, Eksioglu U, Duman S. Incidence and risk factors in secondary glaucomas after blunt and penetrating ocular trauma. J Glaucoma 2007;16:68590.

13. Mirza GE. Non-penetrating traumas and glaucoma. In: Firat E, Atilla H, Evren O, editors. 26th National ophthalmology course textbook. Ankara: The Glaucoma-Turkish Ophthalmology Society 2006. p. 129-42.

14. Polansky JR, Weinreb RN. Steroids as anti-inflammatory agents. In: Sears ML, editor. Pharmacology of the eye. Berlin: Springer-Verlag; 1984. p. 460-538.

15. Wordinger RJ, Clark AF. Effects of glucocorticoids on the trabecular meshwork: towards a better understanding of glaucoma. Prog Retin Eye Res 1999;18:629-67. 